\title{
Impact of Magnesium Fertilization on Yield and Nutrients Uptake by Maize Grown on two Different Soils
}

\author{
R. A. El-Dissoky*, Faten A. Al-Kamar and R. M. Derar \\ Soils, Water and Environment Res. Inst., Agric. Res. Center, Giza, Egypt
}

\begin{abstract}
$\mathbf{M}$ AGNESIUM deficiency occurs as a result to its low content in soil, competition with other cations especially calcium and potassium and its removal by crops. This study was conducted to investigate the effect of applying magnesium at various rates and methods: as a soil application, i.e. $0,25,50,75$ and $100 \mathrm{~kg}$ magnesium sulphate $\mathrm{fed}^{-1}$, and as foliar spray of 0.25 and $0.5 \% \mathrm{Mg}$ twice on maize yield components, nutrient status and uptake and the relationships between $\mathrm{Mg}$ and both $\mathrm{K}$ and $\mathrm{Ca}$ for maize grown on two different soils during two summer growing seasons of 2015 and 2016. The first experiment was carried out in clay loam soil at Talkha District, Dakahlia Governorate ( $\left.31^{\circ} 16^{\prime} 72.71^{\prime \prime} \mathrm{N}, 31^{\circ} 46^{\prime} 25.80^{\prime \prime} \mathrm{E}\right)$, and the second in sandy soil at Ismailia Agricultural Research Station (30.6 $35^{\circ} 30^{\prime}$ ' N, $32.2^{\circ} 14^{\prime} 50^{\prime \prime}$ E), Egypt. Results showed that the application of Mg-rates significantly increased grain and stalk yields, 100-grain weight, grain content of oil, protein, $\mathrm{P}, \mathrm{K}, \mathrm{Ca}, \mathrm{Mg}$, $\mathrm{Mn}$ and $\mathrm{Zn}$, and the uptake of $\mathrm{N}, \mathrm{P}, \mathrm{K}, \mathrm{Ca}, \mathrm{Mg}, \mathrm{Fe}, \mathrm{Mn}$ and $\mathrm{Zn}$ by stalk yield, with the superiority for $\mathrm{Mg}$-rates $50 \mathrm{Kg} \mathrm{fed}^{-1}$ and $0.5 \% \mathrm{Mg}$ foliar spray in clay loam soil, and for the rate $75 \mathrm{Kg} \mathrm{fed}^{-1}$ in sandy soil. Relationships between $\mathrm{Mg}$ and $\mathrm{K}$ or $\mathrm{Ca}$ at ear leaf demonstrated that $\mathrm{K}: \mathrm{Mg}$ and $\mathrm{Ca}: \mathrm{Mg}$ ratios increased with the foliar spray of $\mathrm{Mg}$ and soil addition of Mg-rates up to $50 \mathrm{~kg} \mathrm{fed}^{-1}$ in both soils.
\end{abstract}

Keywords: Magnesium fertilization, Maize yield, Soil texture and Nutrient relationships and Uptake.

\section{Introduction}

Maize is one of the most important cereal crops in Egypt that ranks as the third crop after wheat and rice. It is used as a human food and animal feed. It is characterized by a high potential of biomass and grain yield, furthermore it uptakes great amounts of nutritive elements from the soil. The role of magnesium as one of the essential nutrients for plant growth; is being a component of the chlorophyll molecule; it serves as a cofactor in most enzymes that activate phosphorylation processes as a bridge between pyrophosphate structures of ATP or ADP, DNA, RNA and the enzyme molecule; and it is essential for amino acids and fat synthesis (Mengel and Kirkby, 2001). Nevertheless, such element received little attention terms of fertilization. Kacar and Katkat (2007) noticed that chemical fertilizers produced through developing technology do not include $\mathrm{Mg}$, although growing recently developed varieties of plants, having high nutritional elements uptakes besides their ability to remove higher amounts of nutrients from soil.
In principle there are two reasons for $\mathrm{Mg}$ deficiency to occur, absolute deficiency and cation competition. Absolute deficiency can be a consequence of (1) low $\mathrm{Mg}$ contents in the source rocks, (2) $\mathrm{Mg}$ losses from the soil , e.g. by mobilization and subsequent leaching and (3) long-term unbalanced crop fertilization practice neglecting $\mathrm{Mg}$ depletion of soils through crop $\mathrm{Mg}$ removal. Cation competition is a consequence of nutrient imbalances in soils. It is commonly known that the uptake of $\mathrm{Mg}$ is strongly influenced by the availability of other cations like $\mathrm{NH}_{4}, \mathrm{Ca}$ and K. Nutrient imbalances in the soil could be associated with fertilization practice (Fageria, 2001, Römheld \& Kirkby, 2007 and Gransee \& Fuhrs, 2013). In this respect, Pathak \& Kalra (1971) and Singh \& B L Singh (1986) noted that the higher supply of $\mathrm{K}$ depressed the $\mathrm{Mg}$ uptake. Marschner (1995) in nutrient solution experiments showed that high availability of the cations $\mathrm{Ca}, \mathrm{K}$ and $\mathrm{Mn}$ can lead to strong decreases in $\mathrm{Mg}$ uptake.

*Corresponding author email: r.eldissoky@yahoo.com 
Symptoms of Mg deficiencies on plants could be related to other nutrient status in soil. Gunes et al. (2002) stated that not only Mg deficiency occurs from lower amount of $\mathrm{Mg}$ in soil, but also due to competition with other cations such as $\mathrm{H}^{+}, \mathrm{K}^{+}, \mathrm{NH}_{4}^{+}, \mathrm{Ca}^{++}$and $\mathrm{Mn}^{++}$. Schulte (2004) demonstrated that deficiency of $\mathrm{Mg}$ appears in sandy soils at the application of high rates of $\mathrm{K}^{+}$ and $\mathrm{NH}_{4}^{+}$fertilizers, since high concentrations of these cations in the soil solution interfere (antagonistic effect) with Mg uptake by plants, and usually does not occur when the soil contains more exchangeable $\mathrm{Mg}$ than exchangeable $\mathrm{K}$. He added that the optimum soil test levels for available $\mathrm{Mg}$ are 51-250 ppm for sandy soils and of 101-500 ppm for all other soils.

Jacobsen (1993) stated that $\mathrm{K}: \mathrm{Mg}$ and $\mathrm{Ca}: \mathrm{Mg}$ ratios are important for balanced $\mathrm{Mg}$ nutrition. When the supply of potassium is insufficient, the rate of $\mathrm{Mg}$ uptake by plants also decreases, but on the other hand, the too excessive doses of potassium fertilizers negatively influence nutrient balance in the plant. Kovacevic et al. (2004) showed that high correlations were found between ear-leaf $\mathrm{Mg}$ (negative correlations) and ear-leaf $\mathrm{K}$ as well as ear-leaf $\mathrm{Ca}$ (positive correlations). They found that the share of $\mathrm{Mg}$ in the sum of $\mathrm{K}+\mathrm{Ca}+\mathrm{Mg}$ among the tested corn hybrids ranged from 9.3 to $21.3 \%$, also $\mathrm{K}: \mathrm{Mg}$ ratio in the ear leaf ranged from 1.78 to even 6.56 , whereas $\mathrm{Ca}: \mathrm{Mg}$ ratio has less variable property than $\mathrm{K}: \mathrm{Mg}$ ratio since the values ranged from 1.94 to 3.44 . Fertilization programs in Egypt for almost crops neglected application of $\mathrm{Mg}$ as a macronutrient. However, many studies showed the importance of magnesium fertilization for increasing crops productivity. Under the Egyptian conditions, Darwish et al. (1997) found that the application of $\mathrm{MgSO}_{4}$ as soil or foliar application resulted in significant increases in 100-seed weight, seed and oil yields of sun flower as well as seed contents of protein and oil. On clayey soil, Ashoub et al. (2003) found that applying magnesium sulphate fertilization of 7.5 or 15 $\mathrm{Kg} \mathrm{fed}^{-1}$ as soil application, or twice foliar spray applications of 0.5 or $1.0 \%$ caused significant increases in the dry matter per plant at the age of 49 days, the head diameter, the weight of 100 seeds, the seed yield per plant, seed, straw and biological yields fed ${ }^{-1}$ with the exception of 7.5 $\mathrm{kg} \mathrm{fed}^{-1}$. Badran et al. (2004) studied the growth of wheat grown on calcareous soil, and reported that the highest grain, straw and protein yields, plant height, 1000-grain weight and grain minerals content $(\mathrm{N}, \mathrm{P}, \mathrm{K}$ and $\mathrm{Mg}$ ) were gained by the application of $75 \mathrm{~kg} \mathrm{~N}^{-1} \mathrm{fed}^{-1}$ under foliar spraying of $400 \mathrm{~L} \mathrm{fed}^{-1}$ magnesium sulphate $6 \%$ solution.

Barlog and Frackowiak-Pawlak (2008) found that potassium fertilization increased the average maize grain yield by $2.3 \%$, but the marked grain yield increase was reached owing to the application of both $\mathrm{K}$ and $\mathrm{Mg}$ at the rates 150 and $16.3 \mathrm{~kg} \mathrm{ha}^{-1}$, respectively in the field studies in loamy sand to loamy soils. Szulc (2009) showed that the highest $\mathrm{N}, \mathrm{K}$ and $\mathrm{Mg}$ contents in dry plant matter (37.0, 42.18 and $2.65 \mathrm{~g} \mathrm{~kg}^{-1}$, respectively) were found by maize fertilized with $15 \mathrm{~kg} \mathrm{Mg} \mathrm{ha}^{-1}$ applied in rows, in comparison with $0 \mathrm{~kg}$ and $15 \mathrm{~kg} \mathrm{Mg} \mathrm{ha}{ }^{-1}$ broadcasting. Rasul et al. (2011) found that the application of $80 \mathrm{~kg} \mathrm{Mg} \mathrm{ha}{ }^{-1}$ as $\mathrm{MgSO}_{4} \cdot 7 \mathrm{H}_{2} \mathrm{O}$ and $140 \mathrm{~kg} \mathrm{P} \mathrm{ha}^{-1}$ recorded the highest value of grain yield $\left(5605.2 \mathrm{~kg} \mathrm{ha}^{-1}\right)$ of wheat grown in silty clay loam soil. In a field study in clay loam soil under semi-arid condition, Ertiftik and Zengin (2016) stated that synergic relations were found between $\mathrm{Mg}$ and $\mathrm{P}$ and $\mathrm{Fe}$ in maize leaves at the soil applied of $\operatorname{Mg}(0,20,40$ and $60 \mathrm{~kg} \mathrm{MgO} \mathrm{ha}^{-1}$ as magnesium sulfate).

This study aims to investigate the response of maize yield grown in two different soil textures (clay loam and sandy soils) under the Egyptian conditions to magnesium fertilization and its effect on nutrients status in plant and grain and also the relationships between $\mathrm{Mg}$ and other nutrients.

\section{Materials and Methods}

Two field experiments were conducted in two different texture soils to investigate the response of maize to $\mathrm{Mg}$ fertilization during the two successful summer growing seasons of 2015 and 2016. The first experiment was performed in clay loam soil at Batra Village, Talkha District, Dakahlia Governorate (Latitude 31 ${ }^{\circ} 16^{\prime} 72.71$ " $\mathrm{N}$, Longitude $31^{\circ} 46^{\prime} 25.80^{\prime \prime} \mathrm{E}$ ), and the second experiment was conducted in sandy soil at Ismailia Agricultural Research Station, Agricultural Research Center (Latitude $30.6^{\circ} 35^{\prime} 30^{\prime \prime} \mathrm{N}$, Longitude $32.2^{\circ} 14^{\prime} 50^{\prime \prime} \mathrm{E}$ ), Ismailia Governorate, Egypt.

Soil samples were taken from the surface layer $(0-30 \mathrm{~cm})$ before sowing of each experiment, and then some physical and chemical properties were 
analyzed according to Jackson (1967) and Hesse

(1971) as shown in Table 1.

TABLE 1. Some physical and chemical properties of the study soils

\begin{tabular}{|c|c|c|c|c|c|c|c|}
\hline \multirow{2}{*}{\multicolumn{2}{|c|}{ Properties }} & \multirow{2}{*}{\multicolumn{2}{|c|}{ Talkha Site }} & \multirow{2}{*}{\multicolumn{2}{|c|}{ Properties }} & \multicolumn{2}{|c|}{ Site } \\
\hline & & & & & & Talkha & Ismailia \\
\hline \multirow{3}{*}{$\begin{array}{l}\text { Particle size } \\
\text { distribution } \%\end{array}$} & Sand & 34.45 & 92.75 & \multicolumn{2}{|c|}{${ }^{* *} \mathrm{EC}\left(\mathrm{dSm}^{-1}\right)$} & 2.04 & 1.2 \\
\hline & Silt & 30.30 & 0.75 & \multirow[b]{2}{*}{$\begin{array}{l}\text { Soluble } \\
\text { Cations }\end{array}$} & $\mathrm{Ca}^{++}$ & 7.0 & 4.2 \\
\hline & Clay & 35.25 & 6.50 & & $\mathrm{Mg}^{++}$ & 5.0 & 2.5 \\
\hline \multicolumn{2}{|l|}{ Texture } & Clay loam & Sandy & \multirow[t]{2}{*}{$\left(\mathrm{mM} \mathrm{L}^{-1}\right)$} & $\mathrm{Na}^{+}$ & 7.1 & 4.95 \\
\hline \multicolumn{2}{|l|}{ Saturation percent } & 65.0 & 21 & & $\mathrm{~K}^{+}$ & 0.54 & 0.35 \\
\hline \multicolumn{2}{|l|}{ Organic matter \% } & 0.93 & 0.31 & \multirow[b]{2}{*}{$\begin{array}{l}\text { Soluble } \\
\text { anions }\end{array}$} & $\mathrm{CO}_{3}^{--}$ & -- & -- \\
\hline \multicolumn{2}{|l|}{$\mathrm{CaCO}_{3} \%$} & 2.40 & 0.49 & & $\mathrm{HCO}_{3}^{-}$ & 4.0 & 2.7 \\
\hline \multicolumn{2}{|l|}{ " $\mathrm{pH}$} & 8.16 & 7.82 & \multirow[t]{2}{*}{$\left(\mathrm{mM} \mathrm{L}^{-1}\right)$} & $\mathrm{Cl}^{-}$ & 12.5 & 6.8 \\
\hline Bulk density $\left(\mathrm{g} \mathrm{cm}^{-3}\right)$ & & 1.20 & 1.71 & & $\mathrm{SO}_{4}^{--}$ & 3.14 & 2.5 \\
\hline \multicolumn{8}{|c|}{ Available nutrients ( $\mathrm{mg} \mathrm{kg}^{-1}$ ) } \\
\hline \multicolumn{2}{|l|}{$\mathrm{N}$} & 70 & 34 & \multicolumn{2}{|c|}{$\mathrm{Mg}$} & 180 & 70 \\
\hline \multicolumn{2}{|l|}{$\mathrm{P}$} & 15 & 11 & \multicolumn{2}{|c|}{$\mathrm{Fe}$} & 3.80 & 2.40 \\
\hline \multicolumn{2}{|l|}{ K } & 380 & 139 & \multicolumn{2}{|c|}{$\mathrm{Mn}$} & 2.15 & 1.22 \\
\hline \multicolumn{2}{|l|}{$\mathrm{Ca}$} & 1100 & 300 & \multicolumn{2}{|c|}{$\mathrm{Zn}$} & 0.75 & 0.30 \\
\hline
\end{tabular}

"pH in soil : water suspension1:2.5, $\quad{ }^{* *} \mathrm{EC}$ in soil paste extract.

\section{Experiments design and treatments}

The experiments were performed in a Complete Randomized Blocks Design with three replicates. The experimental plot area was $10.5 \mathrm{~m}^{2}$ (5 lines $\mathrm{x} 0.60 \mathrm{~m}$ width $\mathrm{x} 3.5 \mathrm{~m}$ length). Each experiment consisted of seven treatments of magnesium sulphate fertilizer $(10 \% \mathrm{Mg})$ as a soil application and foliar spraying on plants as follows:

- $\mathrm{T}_{1}$ : control (without $\mathrm{Mg}$ application).

- $\mathrm{T}_{2}: 25 \mathrm{~kg} \mathrm{MgSO}_{4} \mathrm{fed}^{-1}$ as a soil application.

- $\mathrm{T}_{3}: 50 \mathrm{~kg} \mathrm{MgSO}_{4} \mathrm{fed}^{-1}$ as a soil application.

- $\mathrm{T}_{4}: 75 \mathrm{~kg} \mathrm{MgSO}_{4} \mathrm{fed}^{-1}$ as a soil application.

- $\mathrm{T}_{5}: 100 \mathrm{~kg} \mathrm{MgSO}_{4} \mathrm{fed}^{-1}$ as a soil application.

- $\mathrm{T}_{6}: 0.25 \% \mathrm{Mg}$ foliar spraying (twice).

- $\mathrm{T}_{7}: 0.5 \% \mathrm{Mg}$ foliar spraying (twice).

\section{Sowing and fertilization}

Maize seeds (c.v. single hybrid 30-K-08) were sown at the $1^{\text {st }}$ season on $25^{\text {th }}$ April and $15^{\text {th }}$ May 2015 and harvested on $25^{\text {th }}$ August and $15^{\text {th }}$ September 2015 for Talkha (clay loam soil) and Ismailia (sandy soil) sites, respectively; and were sown at the $2^{\text {nd }}$ season on $27^{\text {th }}$ April and $11^{\text {th }}$ May 2016 and harvested on $28^{\text {th }}$ August and $14^{\text {th }}$ September 2016 in Talkha and Ismailia sites, respectively.
Phosphorus fertilizer was added at the rate of $200 \mathrm{Kg} \mathrm{fed}{ }^{-1}$ as super phosphate $\left(15 \% \mathrm{P}_{2} \mathrm{O}_{5}\right)$ with soil preparation before sowing for both experiments. Nitrogen fertilizer was added at a rate of $120 \mathrm{~kg} \mathrm{~N}$ fed $^{-1}$ as ammonium nitrate $(33.5 \%$ $\mathrm{N})$ at two equal doses with the second and third irrigation for maize grown in clay loam soil, as well as it was applied at a rate of $140 \mathrm{Kg} \mathrm{N}$ fed $^{-1}$ as ammonium sulphate $(20.5 \% \mathrm{~N})$ at four equal doses, all two week after emergence for maize grown in sandy soil. The potassium fertilizer was applied at a rate of $24 \mathrm{~kg} \mathrm{~K}_{2} \mathrm{O}$ fed $^{-1}$ as potassium sulphate $\left(\begin{array}{lll}48 \% & \mathrm{~K}_{2} \mathrm{O}\end{array}\right)$ with $1^{\text {st }}$ irrigation after sowing for maize grown in clay loam soil, and with sowing in sandy soil. Also, all recommended field practices for maize crop were carried out for the experiments. The field irrigation system was surface irrigated in lines every 15 days in clay loam soil, and it was drip irrigated every two days in sandy soil.

\section{Application of magnesium treatments}

Soil applications of $\mathrm{Mg}$ treatments $\left(\mathrm{T}_{2}, \mathrm{~T}_{3}\right.$, $\mathrm{T}_{4}$ and $\mathrm{T}_{5}$ ) were applied as magnesium sulphate $(10 \% \mathrm{Mg})$ with the second irrigation for experimental at clay loam soil and after sowing by four weeks for experiment in sandy soil. Concerning foliar spraying of $\mathrm{Mg}$ treatments $\left(\mathrm{T}_{6}\right.$ 
and $\left.\mathrm{T}_{7}\right), \mathrm{Mg}$ was sprayed at the concentration of 0.25 and $0.5 \% \mathrm{Mg}$ as magnesium sulphate $(10 \%$ $\mathrm{Mg}$ ) twice after 35 and 50 days from sowing (at the rate of $\left.400 \mathrm{~L} \mathrm{fed}^{-1}\right)$.

\section{Harvest and chemical analysis}

At harvesting stage, plants at each plot were collected and yield parameters were recorded; Plant height $(\mathrm{cm})$, plant dry weight $(\mathrm{g})$, ear length $(\mathrm{cm})$, ear weight $\left(\mathrm{g}\right.$ plant $\left.^{-1}\right), 100$-grain weight $(\mathrm{g})$, grain weight per ear $(\mathrm{g})$, grain yield $\left(\mathrm{kg} \mathrm{fed}^{-1}\right)$ and stalk yield $\left(\mathrm{kg} \mathrm{fed}^{-1}\right)$. Samples of grain and ear leaf were taken randomly from each plot for chemical analysis to determine nitrogen, phosphorus, potassium, calcium, magnesium, iron, manganese and zinc concentrations and uptakes. Nitrogen was determined using Kjeldahl method, phosphorus was determined spectrophotometrically and potassium was determined using flame photometer. Calcium, magnesium, iron, zinc and manganese were determined using atomic adsorption plasma - ULTIMA 2ICP- OES (Inductively Coupled Plasma Optical Emission Spectrometry) at the Unite of Soil and Water Analysis at Soils, Water and Environment Research Institute, ARC, Egypt. The oil content was determined using Soxhlet method according to A.O.A.C. (1990). Protein content was calculated as follows: $($ protein $\%=\mathrm{N} \%$ in grain $\times 5.70$ ).

The statistical analysis was done according to Gomez and Gomez (1984) and means of treatments were compared against least significant differences test (LSD) at 5\% and Duncan's multiple comparisons Test.

\section{$\underline{\text { Results and Discussion }}$}

\section{Soil characteristics}

It is clear from the results in Table 1 that soils at Talkha and Ismailia sites were characterized by a slightly alkaline $\mathrm{pH}$ ( 8.16-7.82) and non saline (2.04- $1.2 \mathrm{dSm}^{-1}$ ). Soil of Talkha site (clay loam soil) was moderate in the available $\mathrm{P}, \mathrm{K}$ and $\mathrm{Mg}$, high in the available $\mathrm{N}$ and $\mathrm{Ca}$ and low in the available Fe, $\mathrm{Mn}$ and $\mathrm{Zn}$; whereas soil in Ismailia site (sandy) was moderate in the available N, P, K and $\mathrm{Ca}$ and low in the available $\mathrm{Mg}, \mathrm{Fe}, \mathrm{Mn}$ and $\mathrm{Zn}$. Concerning the relationships between $\mathrm{Mg}$ and $\mathrm{Ca}$ and $\mathrm{K}$ in terms of soil fertility, Jokinen (1981) illustrated that the most suitable balances between exchangeable $\mathrm{Ca}, \mathrm{K}$ and $\mathrm{Mg}$ are supposed to be $\mathrm{Ca}: \mathrm{K}=12, \mathrm{Ca}: \mathrm{Mg}=6$ and $\mathrm{Mg}: \mathrm{K}=2$. Whereas, the results of soil analysis before sowing (Table 1) showed that the pervious ratios were; 2.89 , 6.11 and 0.47 in Talkha clay loam soil, and 2.16,
4.28 and 0.50 in Ismailia sandy soil, respectively. Therefore, from the previous ratios there were imbalances between these cations in two soils according to Jokinen (1981), whereas Ca was high in clay loam soil. In this respect Ertiftik and Zengin (2016) found that even if $\mathrm{Mg}$ was present in the soil in adequate amounts, the plants could not uptake sufficient amounts, and hidden or visible deficiency symptoms could occur.

\section{Maize yield and its components}

\section{In Talkha site}

Data in Table 2 show that the application of $\mathrm{Mg}$-rates significantly increased grain and stalk yields, plant weight, ear weight plant $^{-1}$ and grain weight ear ${ }^{-1}$, but had insignificant effect on ear length. The superior in grain yield was recorded with the application of $\mathrm{Mg}$-rate $\mathrm{T}_{7}$, but without significant differences with yield recorded with Mg-rates; $\mathrm{T}_{3}, \mathrm{~T}_{4}$ and $\mathrm{T}_{6}$. Grain yield increased by $8.11,12.77,10.44,9.51,11.84$ and $13.99 \%$ with the application of Mg-rates; $\mathrm{T}_{2}, \mathrm{~T}_{3}, \mathrm{~T}_{4}, \mathrm{~T}_{5}$ and $\mathrm{T}_{7}$ as compared with the control $\left(\mathrm{T}_{1}\right)$, respectively. Stalk yield significantly increased with $\mathrm{Mg}$-rates application compared with the control $\left(\mathrm{T}_{1}\right)$ up to $\mathrm{T}_{3}$, since the differences among $\mathrm{Mg}$-rates were insignificant. Stalk yield increased by 22.04 , $26.33,23.43,22.04,23.65$ and $26.18 \%$ with the application of Mg-rates, respectively as compared with the control. As well, the differences among the values recorded with the application of $\mathrm{Mg}$ rates $T_{2}, T_{3}$ and $T_{7}$ for plant dry weight, ear weight and grain weight ear ${ }^{-1}$ were insignificant. So, these results demonstrate positive response of maize grown in clay loam soil to $\mathrm{Mg}$ fertilization; whereas foliar spray of $0.5 \% \mathrm{Mg}\left(\mathrm{T}_{7}\right)$ had the superior effect on plant dry weight, ear length, grain weight ear ${ }^{-1}$, grain and stalk yields.

It is clear from the previous results, the response to application of Mg-rates, which may be attributed to the initial status of soil before sowing (Table 1); whereas soil was moderate in its fertility of $\mathrm{Mg}$ and $\mathrm{K}$, and high in available $\mathrm{Ca}$, that may affect the supply of $\mathrm{Mg}$ to plant; since there is a competition among $\mathrm{Mg}, \mathrm{K}$ and $\mathrm{Ca}$. Also, the level of available Mg was insufficient (Fageria 2001, Römheld \& Kirkby, 2007 and Gransee \& Fuhrs, 2013).

\section{In Ismailia site}

Results in Table 2 illustrate that maize grain and stalk yields significantly increased with the application of $\mathrm{Mg}$ rates, since these increases were the highest with $\mathrm{Mg}$-rate $\mathrm{T}_{4}\left(75 \mathrm{Kg} \mathrm{MgSO}_{4}\right.$ 
$\left.\mathrm{fed}^{-1}\right)$. Grain and stalk yields increased by 11.66 and $11.72 \%$ with the addition of Mg-rate $\mathrm{T}_{4}$ as compared with the control $\left(\mathrm{T}_{1}\right)$; while they increased by 6.04 and $8.14 \%$ with foliar spray of $0.5 \% \mathrm{Mg}\left(\mathrm{T}_{7}\right)$, respectively. Also, the application of $\mathrm{Mg}$ rates had a significant effect on plant weight, ear weight plant $^{-1}$, ear length and grain weight ear ${ }^{-1}$. Furthermore, results showed that soil application of $\mathrm{Mg}$-rates was more effective on maize yield and its components as compared with foliar spray of $\mathrm{Mg}$.

From the previous results, it is clear that there were positive response from maize yield grown on clay loam and sandy soils to the application of Mg-rates; which were the highest with Mgrate $T_{7}$ for maize grown on clay loam soil, and with $\mathrm{T}_{4}$ for maize grown on sandy soil. These responses may be attributed to the initial level of available $\mathrm{Mg}$ in soil before sowing as shown in Table 1 that was moderate in clay loam soil and low in sandy soil, as well as, to imbalances between $\mathrm{Mg}$ and $\mathrm{Ca}$ and $\mathrm{K}$ as shown in soil characteristics which reflects on the soil supply ability of $\mathrm{Mg}$ and consequently on maize yield (Römheld \& Kirkby, 2007, Gransee \& Fuhrs, 2013 and Ertiftik \& Zengin, 2016).

\section{Grain quality and its contents \\ In Talkha site}

Data in Table 3 illustrate that 100-grain weight, oil and protein\% (as grain quality) significantly increased with the application of Mg-rates. The highest value of 100-grain weight and oil\% was recorded with the application of $\mathrm{Mg}$-rate $\mathrm{T}_{7}$. However, the differences among the obtained results of 100-grain weight recorded with other Mg-rates were insignificant. Concerning grain content of $\mathrm{P}, \mathrm{K}, \mathrm{Ca}, \mathrm{Mg}, \mathrm{Fe}, \mathrm{Mn}$ and $\mathrm{Zn}$, it is clear from the results that grin content of $\mathrm{P}, \mathrm{K}, \mathrm{Ca}$, $\mathrm{Mg}, \mathrm{Mn}$ and $\mathrm{Zn}$ significantly increased with the application of Mg-rates up to $\mathrm{T}_{3}\left(50 \mathrm{~kg} \mathrm{MgSO}_{4}\right)$, but had insignificant effect on Fe content. These increases in grain content of protein, oil, $\mathrm{P}, \mathrm{K}$, $\mathrm{Ca}, \mathrm{Mg}, \mathrm{Fe}, \mathrm{Mn}$ and $\mathrm{Zn}$ mean increase the quality and the nutritional value of grain. Singh \& Singh (1986), Rasul et al. (2011) and Ertiftik \& Zengin (2016) reported similar results.

\section{In Ismailia site}

Application of Mg-rates as soil or foliar spraying had significant effect on 100-grain weight, protein $\%$ and oil $\%$ in maize grain. The values of 100-grain weight and protein content significantly increased up to $\mathrm{T}_{3}$. Also, the application of Mg-rates significantly increased grain content of $\mathrm{P}, \mathrm{K}, \mathrm{Ca}, \mathrm{Mn}$ and $\mathrm{Zn}$, but had insignificant effect on grain content of $\mathrm{Mg}$ and $\mathrm{Fe}$. The highest grain content of $\mathrm{Ca}, \mathrm{Mg}, \mathrm{Fe}$, $\mathrm{Mn}$ and $\mathrm{Zn}$ were recorded with the application of $\mathrm{Mg}$-rate $\mathrm{T}_{5}\left(100 \mathrm{~kg} \mathrm{MgSO}_{4} \mathrm{fed}^{-1}\right)$, but this content was insignificant with that recorded with $\mathrm{Mg}$-rate $\mathrm{T}_{4}\left(75 \mathrm{~kg} \mathrm{MgSO}_{4} \mathrm{fed}^{-1}\right)$.

It is obvious from the mentioned results for grain content of maize grown in clay loam and sandy soils, that the application of Mg-rates had a positive effect on 100-grain weight, oil and protein percentages and its content of phosphorus, calcium, iron and zinc; and these results are in accordance with that obtained by Ertiftik and Zengin (2016). In this respect, Mengel \& Kirkby (2001), Grzebisz (2004) and Barlog \& Frackowiak-Pawlak (2008) stated that $\mathrm{K}$ and $\mathrm{Mg}$ exerted a positive influence on the weight of 1000 kernels, since both elements participate in the transport of carbohydrates to the sink organs. As well, these results are correlated with the importance of $\mathrm{Mg}$ for the plant; it serves as a cofactor in most enzymes that activate phosphorylation processes as a bridge between pyrophosphate structures of ATP or ADP, DNA, RNA and the enzyme molecule, it is essential for amino acids and fat synthesis (Mengel and Kirkby, 2001). As well, maize is considered as an exhaustive crop, and $\mathrm{Mg}$ both had been found to enhance the carbohydrate content like K.

\section{Ear leaf content of nutrient In Talkha site}

The chemical analysis of ear leaf as shown in Table 4 demonstrate that its content of $\mathrm{N}, \mathrm{P}, \mathrm{K}, \mathrm{Ca}, \mathrm{Mg}, \mathrm{Fe}, \mathrm{Mn}$ and $\mathrm{Zn}$ concentrations significantly increased with the application of Mg-rates. Nitrogen, K, Ca and $\mathrm{Zn}$ concentrations in ear leaf significantly increased with the application of Mg-rates up to $\mathrm{T}_{3}$, however leaf content of $\mathrm{Mg}, \mathrm{Fe}$ and $\mathrm{Mn}$ increased up to $\mathrm{T}_{4}$, since $\mathrm{P}$ content increased with Mg-rates application up to $\mathrm{T}_{5}$ , Moreover, foliar spraying of $0.5 \% \mathrm{Mg}\left(\mathrm{T}_{7}\right)$ increased ear leaf content of $\mathrm{K}, \mathrm{Ca}, \mathrm{Mn}$ and $\mathrm{Zn}$ without significant differences with those recorded with $\mathrm{Mg}$-rates $\mathrm{T}_{3}$ and $\mathrm{T}_{4}$. Increasing the $\mathrm{Mg}$ rate of application up to $\mathrm{T}_{3}$ had a positive effect on the ear leaf content of $\mathrm{K}$ and $\mathrm{Ca}$, but its concentrations decreased with the application of Mg-rates; $\mathrm{T}_{4}, \mathrm{~T}_{5}$ and $\mathrm{T}_{6}$; and this may be returned to the competition among $\mathrm{Mg}, \mathrm{K}$ and $\mathrm{Ca}$ for plant uptake, since 
TABLE 2. Effect of magnesium application rates and methods on maize yield and its components grown in clayey loam and sandy soils

\begin{tabular}{|c|c|c|c|c|c|c|c|}
\hline Parameters & $\begin{array}{c}\text { Plant } \\
\text { height } \\
(\mathrm{cm})\end{array}$ & $\begin{array}{c}\text { Plant } \\
\text { weight } \\
\text { (g) }\end{array}$ & $\begin{array}{c}\text { Ear } \\
\text { length } \\
(\mathrm{cm})\end{array}$ & $\begin{array}{c}\text { Ear } \\
\text { weight } \\
\text { (g) }\end{array}$ & $\begin{array}{c}\text { Grain } \\
\text { weight } \\
\text { ear }^{-1}\end{array}$ & $\begin{array}{c}\text { Grain } \\
\text { yield } \\
\left(\text { kg fed }^{-1}\right)\end{array}$ & $\begin{array}{c}\text { Stalk } \\
\text { yield } \\
\left(\mathrm{kg} \mathrm{fed}^{-1}\right)\end{array}$ \\
\hline \multicolumn{8}{|c|}{ Talkha experiment (clay loam soil) } \\
\hline $\mathrm{T}_{1}:$ Control & $310 \mathrm{c}$ & $251 b$ & $19.5 \mathrm{a}$ & $241 \mathrm{c}$ & $214 d$ & $3429 d$ & $4519 b$ \\
\hline $\mathrm{T}_{2}: 25 \mathrm{~kg} \mathrm{MgSO}_{4} \mathrm{fed}^{-1}$ & $333 a$ & $303 a$ & $19.7 \mathrm{a}$ & $252 b c$ & $232 \mathrm{c}$ & $3707 \mathrm{c}$ & $5515 \mathrm{a}$ \\
\hline $\mathrm{T}_{3}: 50 \mathrm{~kg} \mathrm{MgSO}_{4} \mathrm{fed}^{-1}$ & $327 \mathrm{ab}$ & $314 \mathrm{a}$ & $20.3 \mathrm{a}$ & $274 \mathrm{a}$ & $242 \mathrm{ab}$ & $3867 \mathrm{ab}$ & $5709 a$ \\
\hline $\mathrm{T}_{4}: 75 \mathrm{~kg} \mathrm{MgSO}_{4} \mathrm{fed}^{-1}$ & $315 b c$ & $307 \mathrm{a}$ & $19.8 \mathrm{a}$ & $262 \mathrm{ab}$ & $237 \mathrm{abc}$ & $3787 \mathrm{abc}$ & $5578 \mathrm{a}$ \\
\hline $\mathrm{T}_{5}: 100 \mathrm{~kg} \mathrm{MgSO}_{4} \mathrm{fed}^{-1}$ & $325 \mathrm{ab}$ & $303 a$ & $20.5 \mathrm{a}$ & $260 \mathrm{ab}$ & $235 \mathrm{bc}$ & $3755 b c$ & $5515 \mathrm{a}$ \\
\hline $\mathrm{T}_{6}: 0.25 \% \mathrm{Mg}$ foliar & $315 \mathrm{bc}$ & $307 \mathrm{a}$ & $20.8 \mathrm{a}$ & $270 \mathrm{a}$ & $240 \mathrm{abc}$ & $3835 \mathrm{abc}$ & $5588 \mathrm{a}$ \\
\hline $\mathrm{T}_{7}: 0.5 \% \mathrm{Mg}$ foliar & $317 b c$ & $314 \mathrm{a}$ & $21.0 \mathrm{a}$ & $274 a$ & $244 \mathrm{a}$ & $3909 a$ & $5702 \mathrm{a}$ \\
\hline L.S.D. at $5 \%$ & 13.4 & 17.1 & NS & 16.1 & 7.8 & 124.3 & 421.7 \\
\hline \multicolumn{8}{|c|}{ Ismailia experiment (sandy soil) } \\
\hline $\mathrm{T}_{1}:$ Control & $217 \mathrm{a}$ & $189 \mathrm{~b}$ & $17.5 \mathrm{c}$ & $182 d$ & 155 & $2615 \mathrm{e}$ & $4250 \mathrm{~g}$ \\
\hline $\mathrm{T}_{2}: 25 \mathrm{~kg} \mathrm{MgSO}_{4} \mathrm{fed}^{-1}$ & $217 \mathrm{a}$ & $201 \mathrm{a}$ & $18.9 b$ & $192 \mathrm{c}$ & 162 & $2697 d$ & $4530 \mathrm{~d}$ \\
\hline $\mathrm{T}_{3}: 50 \mathrm{~kg} \mathrm{MgSO} \mathrm{fed}^{-1}$ & $218 \mathrm{a}$ & $209 \mathrm{a}$ & $20.7 \mathrm{a}$ & $196 a b c$ & 169 & $2876 \mathrm{ab}$ & $4695 b$ \\
\hline $\mathrm{T}_{4}: 75 \mathrm{~kg} \mathrm{MgSO}_{4} \mathrm{fed}^{-1}$ & $218 \mathrm{a}$ & $211 \mathrm{a}$ & $20.8 \mathrm{a}$ & $199 \mathrm{ab}$ & 169 & $2920 \mathrm{a}$ & $4748 \mathrm{a}$ \\
\hline $\mathrm{T}_{5}: 100 \mathrm{~kg} \mathrm{MgSO}_{4} \mathrm{fed}^{-1}$ & $218 \mathrm{a}$ & $208 \mathrm{a}$ & $20.1 \mathrm{a}$ & $202 \mathrm{a}$ & 167 & $2845 b$ & $4465 \mathrm{e}$ \\
\hline $\mathrm{T}_{6}: 0.25 \% \mathrm{Mg}$ foliar & $216 \mathrm{a}$ & $201 \mathrm{a}$ & $19.8 \mathrm{ab}$ & $194 \mathrm{bc}$ & 165 & $2673 d$ & $4405 \mathrm{f}$ \\
\hline $\mathrm{T}_{7}: 0.5 \% \mathrm{Mg}$ foliar & $218 \mathrm{a}$ & $204 a$ & $19.9 \mathrm{ab}$ & $196 a b c$ & 167 & $2773 c$ & $4596 c$ \\
\hline L.S.D. at $5 \%$ & Ns & 12.2 & 1.2 & 5.8 & 3.9 & 46.1 & 36.0 \\
\hline
\end{tabular}

TABLE 3. Effect of magnesium application rates and methods on grain contents of maize grown in clayey loam and sandy soils

\begin{tabular}{|c|c|c|c|c|c|c|c|c|c|c|}
\hline \multirow{2}{*}{ Treatments } & \multirow{2}{*}{$\begin{array}{c}\text { 100-grain } \\
\text { weight } \\
\text { (g) }\end{array}$} & \multicolumn{6}{|c|}{$(\%)$} & \multicolumn{3}{|c|}{$\left(\mathrm{mg} \mathrm{kg}^{-1}\right)$} \\
\hline & & Oil & Protein & $\mathbf{P}$ & $\mathbf{K}$ & $\mathbf{C a}$ & Mg & $\mathbf{F e}$ & Mn & Zn \\
\hline \multicolumn{11}{|c|}{ Talkha experiment (clay loam soil) } \\
\hline $\mathrm{T}_{1}$ & $29.49 b$ & $9.97 \mathrm{~d}$ & $5.65 \mathrm{~d}$ & $0.258 \mathrm{de}$ & $0.25 \mathrm{c}$ & $0.057 \mathrm{~b}$ & $0.075 b$ & $547 \mathrm{~b}$ & $7.2 \mathrm{c}$ & $137 \mathrm{~b}$ \\
\hline $\mathrm{T}_{2}$ & $31.11 \mathrm{a}$ & $10.19 \mathrm{c}$ & $6.75 \mathrm{a}$ & $0.271 \mathrm{~d}$ & $0.28 b c$ & $0.058 \mathrm{~b}$ & $0.078 \mathrm{~b}$ & $592 \mathrm{ab}$ & $9.2 \mathrm{~b}$ & $142 b$ \\
\hline $\mathrm{T}_{3}$ & $31.27 \mathrm{a}$ & $10.20 \mathrm{c}$ & $6.84 \mathrm{ab}$ & $0.303 \mathrm{c}$ & $0.36 \mathrm{a}$ & $0.069 \mathrm{ab}$ & $0.085 \mathrm{a}$ & $641 \mathrm{a}$ & $9.7 \mathrm{ab}$ & $166 \mathrm{a}$ \\
\hline $\mathrm{T}_{4}$ & $31.28 \mathrm{a}$ & $10.39 b$ & $7.13 \mathrm{a}$ & $0.352 \mathrm{a}$ & $0.30 \mathrm{~b}$ & $0.078 \mathrm{a}$ & $0.082 \mathrm{ab}$ & $616 a b$ & $10.5 \mathrm{ab}$ & $143 b$ \\
\hline $\mathrm{T}_{5}$ & $31.29 \mathrm{a}$ & $9.57 \mathrm{e}$ & $6.56 \mathrm{~b}$ & $0.249 \mathrm{de}$ & $0.20 \mathrm{~d}$ & $0.059 \mathrm{~b}$ & $0.078 \mathrm{~b}$ & $630 \mathrm{ab}$ & $11.3 \mathrm{a}$ & $145 b$ \\
\hline $\mathrm{T}_{6}$ & $31.28 \mathrm{a}$ & $10.14 \mathrm{c}$ & $6.16 \mathrm{c}$ & $0.329 \mathrm{~b}$ & $0.27 b c$ & $0.062 b$ & $0.080 \mathrm{ab}$ & $553 b$ & $8.8 \mathrm{bc}$ & $153 \mathrm{ab}$ \\
\hline $\mathrm{T}_{7}$ & $31.77 \mathrm{a}$ & $10.52 \mathrm{a}$ & $6.75 b$ & $0.242 \mathrm{e}$ & $0.29 \mathrm{bc}$ & $0.064 \mathrm{~b}$ & $0.085 \mathrm{a}$ & $606 a b$ & $9.7 \mathrm{ab}$ & $168 \mathrm{a}$ \\
\hline L.S.D. at $5 \%$ & 0.75 & 0.087 & 0.29 & 0.022 & 0.04 & 0.012 & 0.006 & NS & 1.78 & 15.5 \\
\hline \multicolumn{11}{|c|}{ Ismailia experiment (sandy soil) } \\
\hline $\mathrm{T}_{1}$ & $30.50 \mathrm{c}$ & $9.16 \mathrm{c}$ & $5.44 d$ & $0.380 \mathrm{c}$ & $0.403 \mathrm{c}$ & $0.080 \mathrm{~b}$ & $0.095 \mathrm{a}$ & $486 \mathrm{~b}$ & $9.3 \mathrm{c}$ & $184 d$ \\
\hline $\mathrm{T}_{2}$ & $32.30 \mathrm{c}$ & $9.21 \mathrm{c}$ & $6.37 \mathrm{~b}$ & $0.410 \mathrm{ab}$ & $0.433 \mathrm{ab}$ & $0.120 \mathrm{a}$ & $0.099 \mathrm{a}$ & $549 \mathrm{ab}$ & $9.7 \mathrm{c}$ & $188 \mathrm{~cd}$ \\
\hline $\mathrm{T}_{3}$ & $37.20 \mathrm{a}$ & $9.25 \mathrm{bc}$ & $6.75 \mathrm{a}$ & $0.360 \mathrm{~d}$ & $0.440 \mathrm{a}$ & $0.088 \mathrm{~b}$ & $0.108 \mathrm{a}$ & $586 a$ & $11.7 \mathrm{bc}$ & $208 b c$ \\
\hline $\mathrm{T}_{4}$ & $36.50 \mathrm{ab}$ & $9.38 \mathrm{~b}$ & $6.82 \mathrm{a}$ & $0.343 \mathrm{e}$ & $0.417 \mathrm{abc}$ & $0.073 b$ & $0.115 \mathrm{a}$ & $566 a$ & $14.2 \mathrm{ab}$ & $215 \mathrm{ab}$ \\
\hline $\mathrm{T}_{5}$ & $35.90 \mathrm{ab}$ & $9.61 \mathrm{a}$ & $5.80 \mathrm{c}$ & $0.340 \mathrm{e}$ & $0.410 \mathrm{bc}$ & $0.123 \mathrm{a}$ & $0.120 \mathrm{a}$ & $594 a$ & $16.0 \mathrm{a}$ & $232 \mathrm{a}$ \\
\hline $\mathrm{T}_{6}$ & $35.10 \mathrm{~b}$ & $9.20 \mathrm{c}$ & $5.57 \mathrm{~cd}$ & $0.420 \mathrm{a}$ & $0.430 \mathrm{ab}$ & $0.073 b$ & $0.096 a$ & $530 \mathrm{ab}$ & $10.3 \mathrm{c}$ & $190 \mathrm{~cd}$ \\
\hline $\mathrm{T}_{7}$ & $36.20 \mathrm{ab}$ & $9.30 \mathrm{bc}$ & $6.27 \mathrm{~b}$ & $0.400 \mathrm{~b}$ & $0.423 \mathrm{abc}$ & $0.093 \mathrm{~b}$ & $0.104 \mathrm{a}$ & $537 \mathrm{ab}$ & $13.3 \mathrm{ab}$ & $220 \mathrm{ab}$ \\
\hline L.S.D. at $5 \%$ & 2.10 & 0.15 & 0.29 & 0.012 & 0.022 & 0.022 & Ns & Ns & 2.59 & 19.9 \\
\hline
\end{tabular}

Egypt. J. Soil Sci., 57, No. 4 (2017) 
TABLE 4. Effect of magnesium application rates and methods on ear leaf contents of maize grown in clayey loam and sandy soils

\begin{tabular}{|c|c|c|c|c|c|c|c|c|}
\hline \multirow{2}{*}{\begin{tabular}{|l} 
Parameters \\
Treatments
\end{tabular}} & \multicolumn{5}{|c|}{$(\%)$} & \multicolumn{3}{|c|}{$\left(\mathrm{mg} \mathrm{kg}^{-1}\right)$} \\
\hline & $\mathbf{N}$ & $\mathbf{P}$ & $\mathbf{K}$ & $\mathbf{C a}$ & Mg & $\mathrm{Fe}$ & Mn & $\mathbf{Z n}$ \\
\hline \multicolumn{9}{|c|}{ Talkha experiment (clay loam soil) } \\
\hline $\mathrm{T}_{1}$ & $1.20 \mathrm{~d}$ & $0.219 \mathrm{f}$ & $1.17 \mathrm{de}$ & $0.88 \mathrm{c}$ & $0.350 \mathrm{~d}$ & $640 \mathrm{e}$ & $27 \mathrm{~d}$ & $112 \mathrm{~d}$ \\
\hline $\mathrm{T}_{2}$ & $1.25 \mathrm{bcd}$ & $0.232 \mathrm{e}$ & $1.21 \mathrm{cde}$ & $0.97 \mathrm{ab}$ & $0.366 \mathrm{c}$ & $686 \mathrm{~cd}$ & $38 \mathrm{~b}$ & $130 \mathrm{bc}$ \\
\hline $\mathrm{T}_{3}$ & $1.33 \mathrm{ab}$ & $0.248 \mathrm{~d}$ & $1.27 \mathrm{ab}$ & $1.03 \mathrm{a}$ & $0.379 b$ & $700 \mathrm{bc}$ & $40 \mathrm{~b}$ & $143 \mathrm{ab}$ \\
\hline $\mathrm{T}_{4}$ & $1.40 \mathrm{a}$ & $0.323 b$ & $1.25 \mathrm{abc}$ & $0.93 b c$ & $0.391 \mathrm{ab}$ & $747 \mathrm{a}$ & $46 \mathrm{a}$ & $148 \mathrm{a}$ \\
\hline $\mathrm{T}_{5}$ & $1.30 \mathrm{bc}$ & $0.374 \mathrm{a}$ & $1.15 \mathrm{e}$ & $0.87 \mathrm{c}$ & $0.403 \mathrm{a}$ & $758 \mathrm{a}$ & $47 \mathrm{a}$ & $133 \mathrm{abc}$ \\
\hline $\mathrm{T}_{6}$ & $1.24 \mathrm{~cd}$ & $0.232 \mathrm{e}$ & $1.22 \mathrm{bcd}$ & $0.90 \mathrm{c}$ & $0.362 \mathrm{~cd}$ & $668 d$ & $34 \mathrm{c}$ & $120 \mathrm{~cd}$ \\
\hline $\mathrm{T}_{7}$ & $1.31 \mathrm{bc}$ & $0.261 \mathrm{c}$ & $1.30 \mathrm{a}$ & $1.00 \mathrm{a}$ & $0.380 \mathrm{~b}$ & $712 b$ & $46 \mathrm{a}$ & $133 \mathrm{abc}$ \\
\hline L.S.D. at $5 \%$ & 0.08 & 0.004 & 0.05 & 0.06 & 0.012 & 20.2 & 4.1 & 16.3 \\
\hline \multicolumn{9}{|c|}{ Ismailia experiment (sandy soil) } \\
\hline $\mathrm{T}_{1}$ & $0.92 \mathrm{c}$ & 0.150 & $0.86 \mathrm{e}$ & $0.75 \mathrm{c}$ & $0.277 \mathrm{~d}$ & $720 \mathrm{~d}$ & $41 \mathrm{~d}$ & $52 d$ \\
\hline $\mathrm{T}_{2}$ & $1.07 \mathrm{~b}$ & 0.160 & $1.03 \mathrm{abc}$ & $0.86 \mathrm{~b}$ & $0.333 \mathrm{~cd}$ & $807 \mathrm{~b}$ & $61 \mathrm{a}$ & $70 \mathrm{bc}$ \\
\hline $\mathrm{T}_{3}$ & $1.17 \mathrm{a}$ & 0.163 & $1.09 \mathrm{a}$ & $0.88 \mathrm{~b}$ & $0.347 \mathrm{bc}$ & $860 \mathrm{a}$ & $55 \mathrm{~b}$ & $72 \mathrm{ab}$ \\
\hline $\mathrm{T}_{4}$ & $1.23 \mathrm{a}$ & 0.170 & $1.05 \mathrm{ab}$ & $0.97 \mathrm{a}$ & $0.400 \mathrm{ab}$ & $870 \mathrm{a}$ & $47 \mathrm{c}$ & $71 \mathrm{bc}$ \\
\hline $\mathrm{T}_{5}$ & $1.00 \mathrm{~b}$ & $0.174 \mathrm{a}$ & $0.97 \mathrm{bcd}$ & $0.90 \mathrm{~b}$ & $0.407 \mathrm{a}$ & $892 \mathrm{a}$ & $62 \mathrm{a}$ & $77 \mathrm{a}$ \\
\hline $\mathrm{T}_{6}$ & $1.02 \mathrm{~b}$ & 0.155 & $0.92 \mathrm{de}$ & $0.79 \mathrm{c}$ & $0.290 \mathrm{~cd}$ & $763 c$ & $46 \mathrm{~cd}$ & $65 c$ \\
\hline $\mathrm{T}_{7}$ & $1.08 \mathrm{~b}$ & 0.162 & $0.95 \mathrm{cde}$ & $0.86 b$ & $0.300 \mathrm{~cd}$ & $786 b c$ & $60 \mathrm{a}$ & $75 \mathrm{ab}$ \\
\hline L.S.D. at $5 \%$ & 0.08 & Ns & 0.082 & 0.054 & 0.056 & 38.2 & 4.5 & 5.4 \\
\hline
\end{tabular}

there were imbalances between these nutrient in soil before sowing (as shown in Table 1). These results are consistent with Römheld \& Kirkby (2007) and Gransee \& Fuhrs (2013).

\section{In Ismailia site}

Results in Table 4 show that the application of Mg-rates had a significant effect on ear leaf content of $\mathrm{N}, \mathrm{K}, \mathrm{Ca}, \mathrm{Mg}, \mathrm{Fe}, \mathrm{Mn}$ and $\mathrm{Zn}$, but had an insignificant effect on ear leaf content of $\mathrm{P}$. Ear leaf content of N, K, Fe and Zn significantly increased with application of Mg-rates up to $\mathrm{T}_{3}$, and up to $\mathrm{T}_{4}$ for ear leaf content of $\mathrm{Ca}$ and $\mathrm{Mg}$. It is obvious from the mentioned results that the application of Mg-rates had a positive effect on maize grown in sandy soil, related with results of analysis of soil before sowing (Table 1), that was low in available $\mathrm{Mg}$. These results are consistent with that obtained by Kovacevic et al. (2004), Szulc (2009) and Ertiftik \& Zengin (2016). In this respect, Izsaki (2006) and Szulc (2009) reported that $\mathrm{P}$ in corn leaves increased with the increases in $\mathrm{Mg}$ doses.
Relationships among ear leaf content of $M g, K$ and $\mathrm{Ca}$

The results in Table 5 show the relationships between ear leaf content of $\mathrm{Mg}, \mathrm{K}$ and $\mathrm{Ca}$ as for $\mathrm{K}: \mathrm{Mg}$ and $\mathrm{Ca}: \mathrm{Mg}$ ratios and the percentage of $\mathrm{Mg}$ for sum $\mathrm{K}+\mathrm{Ca}+\mathrm{Mg}$ concentrations.

\section{In Talkha site}

It is clear from the results that the value of $\mathrm{K}: \mathrm{Mg}$ ratio was not changed with application of Mg-rates $\mathrm{T}_{2}$ and $\mathrm{T}_{3}$, then it decreased with increasing the rate of soil application of $\mathrm{Mg}$ up to $\mathrm{T}_{5}\left(100 \mathrm{~kg} \mathrm{MgSO}_{4}\right)$. However, the ratio of $\mathrm{K}: \mathrm{Mg}$ was increased with foliar spraying of $\mathrm{Mg}$ (as $\mathrm{T}_{6}$ and $\mathrm{T}_{7}$ ). The ratio of $\mathrm{K}: \mathrm{Mg}$ arranged from 2.85 (the lowest ratio that recoded at $\mathrm{T}_{5}$ ) to 3.41 (the highest ratio that recoded at $\mathrm{T}_{7}$ ). The increases in $\mathrm{K}: \mathrm{Mg}$ ratio related with increases that recorded in ear leaf content of $\mathrm{K}$ and $\mathrm{Mg}$ (Table 4). Concerning Ca: $\mathrm{Mg}$ ratio, it is obvious that their values were increased with application of Mg-rates $\mathrm{T}_{2}, \mathrm{~T}_{3}$ and $\mathrm{T}_{7}$, but it decreased with 
Mg-rates; $\mathrm{T}_{4}$ and $\mathrm{T}_{5}$ and $\mathrm{T}_{6}$ compared with control $\left(\mathrm{T}_{1}\right)$. However, the differences among $\mathrm{T}_{2}, \mathrm{~T}_{3}$ and $\mathrm{T}_{7}$ for Ca:Mg ratio were insignificant, which correlated with its concentrations in ear leaf. Regarding \% of $\mathrm{Mg}$ for sum $(\mathrm{K}+\mathrm{Ca}+\mathrm{Mg})$, it is obvious that percentage was significantly increased with application of $\mathrm{Mg}$-rates up to $\mathrm{T}_{5}$ (100 kg MgSO fed $^{-1}$ ), since the highest percent was $16.62 \%$ that recorded with addition of $\mathrm{Mg}$ rate $T_{5}$. It is clear from previous results that application of Mg-rates; $\mathrm{T}_{2}, \mathrm{~T}_{3}$ and $\mathrm{T}_{7}$ (25 and

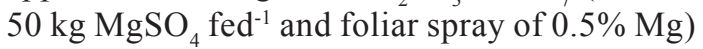
were sufficient to maintain the balance between $\mathrm{Mg}, \mathrm{K}$ and $\mathrm{Ca}$, as well as these results agree with that obtained by Kovacevic et al. (2004).

\section{In Ismailia site}

The results in Table 5 show that $\mathrm{K}: \mathrm{Mg}$ ratio was affected with the application of Mg-rates; whereas it increased with the rate of $\mathrm{T}_{3}$ and foliar spray of $\mathrm{Mg}$ at 0.25 and $0.5 \% \mathrm{Mg}$. $\mathrm{K}: \mathrm{Mg}$ ratio ranged from 2.39 (the lowest ratio that recoded at $\mathrm{T}_{5}$ ) to 3.22 (the highest ratio that recoded at $\mathrm{T}_{7}$ ). Also the ratio of $\mathrm{Ca}: \mathrm{Mg}$ increased with foliar spray of $\mathrm{Mg}$ at 0.25 and $0.5 \% \mathrm{Mg}\left(\mathrm{T}_{6}\right.$ and $\mathrm{T}_{7}$ ), but it decreased with soil application of $\mathrm{Mg}$ rates; $\mathrm{T}_{2}, \mathrm{~T}_{3}, \mathrm{~T}_{4}$ and $\mathrm{T}_{5}$ as compared with control $\left(T_{1}\right)$. This ratio correlated negatively with the increases in ear leaf content of $\mathrm{Mg}$. Concerning percentage of $\mathrm{Mg}$ for sum $(\mathrm{K}+\mathrm{Ca}+\mathrm{Mg})$, it is obvious that increased with application of Mg-rates up to $T_{5}$, which recorded the highest percentage $(17.94 \%)$.

Kovacevic et al. (2004) demonstrated that the share of $\mathrm{Mg}$ in the sum $\mathrm{K}+\mathrm{Ca}+\mathrm{Mg}$ for corn hybrids ranged from 9.3 to $21.3 \%$; $\mathrm{Kg}$ ratio ranged from 1.78 to even 6.56 , whereas $\mathrm{Ca}: \mathrm{Mg}$ ratio ranged from 1.94 to 3.44 . Hence, the obtained results (a shown in Table 5) are in agreement with that result. So it is clear from mentioned results that foliar spray of $0.5 \%$ $\mathrm{Mg}$ was sufficient to maize growing in clay loam soil; as well as soil application of $75 \mathrm{~kg}$ magnesium sulfate per fed-1 was sufficient to maize growing in sandy soil; which maintain on the balance between $\mathrm{K}, \mathrm{Mg}$ and $\mathrm{Ca}$ in ear leaf.

\section{The uptake of nutrient by grain yield In Talkha site}

The data in Table 6 show that the application of $\mathrm{Mg}$-rates significantly increased the uptake of $\mathrm{N}, \mathrm{P}, \mathrm{K}, \mathrm{Ca}, \mathrm{Mg}, \mathrm{Fe}, \mathrm{Mn}$ and $\mathrm{Zn}$ by grain. The uptake of $\mathrm{N}, \mathrm{P}$ and $\mathrm{Ca}$ by grain yield significantly increased up to $\mathrm{T} 4$

Egypt. J. Soil Sci., 57, No. 4 (2017) and then decreased. As well, the uptake of $\mathrm{K}$ by grain significantly increased up to $\mathrm{Mg}$-rate $\mathrm{T}_{3}$ then decreased. However the differences among the uptakes of $\mathrm{N}, \mathrm{Ca}, \mathrm{Mg}, \mathrm{Fe}$, and $\mathrm{Zn}$ by grain that recorded under Mg-rates T3 and T7 were insignificant. So these results illustrate the importance of $\mathrm{Mg}$ supply at the rate of $\mathrm{T}_{3}(50 \mathrm{~kg}$ $\left.\mathrm{MgSO}_{4}\right)$ as soil application or at the rate of $\mathrm{T}_{7}(0.5$ $\% \mathrm{Mg}$ ) as a foliar spray on maize grown in clay loam soil.

\section{In Ismailia site}

The application of $\mathrm{Mg}$-rates as magnesium sulphate had a significant effect on the uptake of N, P, K, Ca, Mg, Fe, Mn and $\mathrm{Zn}$ by grain, since the uptake of $\mathrm{N}, \mathrm{K}, \mathrm{Mg}$, and $\mathrm{Fe}$ significantly increased with soil application of Mg-rates up to the rate of $50 \mathrm{~kg} \mathrm{MgSO}_{4}$ $\left(\mathrm{T}_{3}\right)$. Generally, it is clear from mentioned results that application o $\mathrm{Mg}$-rates improved the uptakes of mostly nutrients by grain, and this demonstrates the importance of $\mathrm{Mg}$ supply for maize crop grown in sandy soil, and this accordance with results that obtained by Izsaki (2006), Szulc (2009) and Ertiftik \& Zengin (2016).

\section{The uptake of nutrient by stalk yield}

The data shown in Table 7 illustrate the effect of the application Mg-rates on the uptake of N, P, $\mathrm{K}, \mathrm{Ca}, \mathrm{Mg}, \mathrm{Fe}, \mathrm{Mn}$ and $\mathrm{Zn}$ by stalk yield of maize grown in clay loam and sandy soils.

\section{In Talkha site}

The results demonstrated that the uptake of $\mathrm{N}, \mathrm{P}, \mathrm{K}, \mathrm{Ca}, \mathrm{Mg}, \mathrm{Fe}, \mathrm{Mn}$ and $\mathrm{Zn}$ by maize stalk yield significantly increased with the application of Mg-rates, with superiority for Mg-rates; $\mathrm{T}_{3}$ and $\mathrm{T}_{7}$ in the mostly for nutrient uptake without significance differences among them. The highest uptake by stalk yield of $\mathrm{N}$ and $\mathrm{Zn}\left(78.0 \mathrm{Kg} \mathrm{fed}^{-1}\right.$ and $827 \mathrm{~g} \mathrm{fed}^{-1}$, respectively) were recorded with soil application of 75 $\mathrm{kg} \mathrm{MgSO}_{4}$ fed $^{-1}\left(\mathrm{~T}_{4}\right)$, moreover the highest uptake of $\mathrm{P}, \mathrm{Mg}, \mathrm{Fe}$ and $\mathrm{Mn}$ were recorded with soil application of $100 \mathrm{~kg} \mathrm{MgSO}_{4} \mathrm{fed}^{-1}$ $\left(\mathrm{T}_{5}\right)$. So these results illustrate that there were synergic relationship among $\mathrm{Mg}$ and these pervious elements, and this accordance with results that obtained by Ertiftik and Zengin (2016). On contrast, the uptake of $\mathrm{K}$ and $\mathrm{Ca}$ were decreased with increasing the rate of soil application of $\mathrm{Mg}$, and this may be attributed to competition among these elements in high rates of Mg supply (Fageria 2001, Guneş et al., 2002, Römheld \& Kirkby 2007 and Gransee \& Fuhrs, 2013). 
TABLE 5. Effect of magnesium application rates and methods on the ratios of investigated cations in ear leaf for maize grown in two different soils.

\begin{tabular}{|c|c|c|c|}
\hline \multirow[b]{2}{*}{ Treatments } & \multicolumn{2}{|c|}{ Ratios } & \multirow{2}{*}{$\begin{array}{c}\text { \% Mg } \\
\text { in } \\
(\mathrm{K}+\mathrm{Ca}+\mathrm{Mg})\end{array}$} \\
\hline & K:Mg & $\mathrm{Ca}: \mathrm{Mg}$ & \\
\hline \multicolumn{4}{|c|}{ Talkha experiment (clay loam soil) } \\
\hline $\mathrm{T}_{1}$ : control & $3.36 \mathrm{ab}$ & $2.50 \mathrm{ab}$ & $14.58 \mathrm{bc}$ \\
\hline $\mathrm{T}_{2}: 25 \mathrm{~kg} \mathrm{MgSO}_{4} \mathrm{fed}^{-1}$ & $3.31 \mathrm{ab}$ & $2.66 \mathrm{a}$ & $14.36 \mathrm{c}$ \\
\hline $\mathrm{T}_{3}: 50 \mathrm{~kg} \mathrm{MgSO}_{4} \mathrm{fed}^{-1}$ & $3.36 \mathrm{ab}$ & $2.72 \mathrm{a}$ & $14.14 \mathrm{c}$ \\
\hline $\mathrm{T}_{4}: 75 \mathrm{~kg} \mathrm{MgSO}_{4} \mathrm{fed}^{-1}$ & $3.20 \mathrm{~b}$ & $2.37 \mathrm{bc}$ & $15.22 b$ \\
\hline $\mathrm{T}_{5}: 100 \mathrm{~kg} \mathrm{MgSO}_{4} \mathrm{fed}^{-1}$ & $2.85 \mathrm{c}$ & $2.17 \mathrm{c}$ & $16.62 \mathrm{a}$ \\
\hline $\mathrm{T}_{6}: 0.25 \% \mathrm{Mg}$ foliar & $3.38 \mathrm{ab}$ & $2.49 \mathrm{ab}$ & $14.55 \mathrm{bc}$ \\
\hline $\mathrm{T}_{7}: 0.5 \% \mathrm{Mg}$ foliar & $3.41 \mathrm{a}$ & $2.64 \mathrm{a}$ & $14.20 \mathrm{c}$ \\
\hline L.S.D. at $5 \%$ & 0.18 & 0.21 & 0.68 \\
\hline \multicolumn{4}{|c|}{ Ismailia experiment (sandy soil) } \\
\hline $\mathrm{T}_{1}:$ control & 3.12 & 2.72 & 14.67 \\
\hline $\mathrm{T}_{2}: 25 \mathrm{~kg} \mathrm{MgSO} \mathrm{fed}^{-1}$ & 3.10 & 2.59 & 14.98 \\
\hline $\mathrm{T}_{3}: 50 \mathrm{~kg} \mathrm{MgSO}_{4} \mathrm{fed}^{-1}$ & 3.16 & 2.54 & 14.94 \\
\hline $\mathrm{T}_{4}: 75 \mathrm{~kg} \mathrm{MgSO}_{4} \mathrm{fed}^{-1}$ & 2.65 & 2.46 & 16.52 \\
\hline $\mathrm{T}_{5}: 100 \mathrm{~kg} \mathrm{MgSO}_{4} \mathrm{fed}^{-1}$ & 2.39 & 2.22 & 17.94 \\
\hline $\mathrm{T}_{6}: 0.25 \% \mathrm{Mg}$ foliar & 3.19 & 2.74 & 14.45 \\
\hline $\mathrm{T}_{7}: 0.5 \% \mathrm{Mg}$ foliar & 3.22 & 2.91 & 14.20 \\
\hline L.S.D. at $5 \%$ & Ns & Ns & Ns \\
\hline
\end{tabular}

TABLE 6. Effect of magnesium application rates and methods on the uptake of some macro- and micronutrients by grain of maize grown in two different soils.

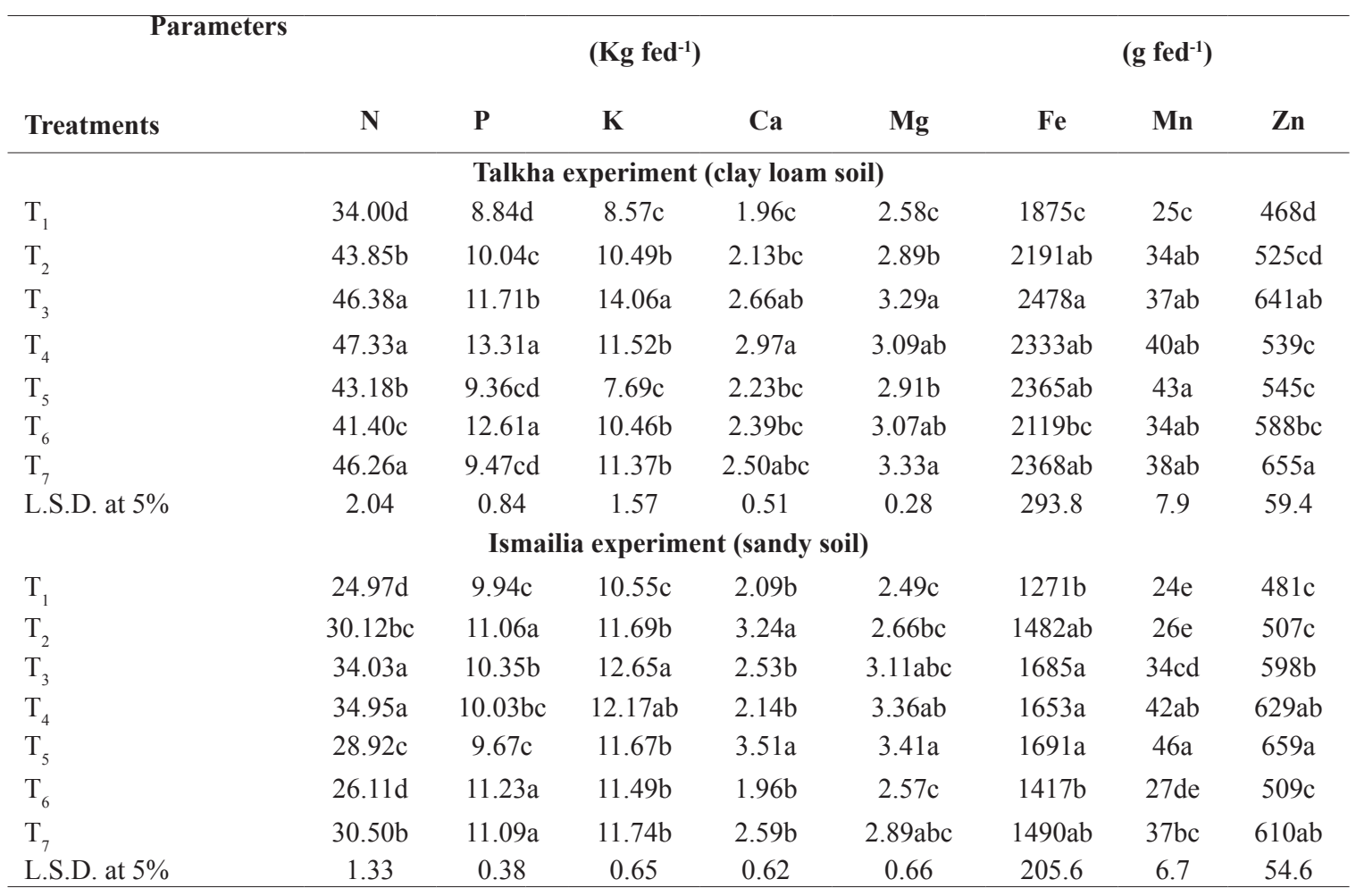


TABLE 7. Effect of magnesium application rates and methods on the uptake of $\mathrm{N}, \mathrm{P}, \mathrm{K}, \mathrm{Ca}, \mathrm{Mg}, \mathrm{Fe}, \mathrm{Mn}$ and $\mathrm{Zn}$ by stalk of maize grown in two different soils.

\begin{tabular}{|c|c|c|c|c|c|c|c|c|}
\hline \multirow[b]{2}{*}{ Treatments } & \multicolumn{5}{|c|}{$\left(\mathrm{Kg} \mathrm{fed}^{-1}\right)$} & \multicolumn{3}{|c|}{$\left(\mathrm{g} \mathrm{fed}^{-1}\right)$} \\
\hline & $\mathbf{N}$ & $\mathbf{P}$ & $\mathbf{K}$ & $\mathrm{Ca}$ & Mg & $\mathrm{Fe}$ & Mn & Zn \\
\hline \multicolumn{9}{|c|}{ Talkha experiment (clay loam soil) } \\
\hline $\mathrm{T}_{1}$ & $54.20 \mathrm{~d}$ & $9.92 \mathrm{f}$ & $53.06 \mathrm{e}$ & $39.59 \mathrm{e}$ & $15.80 \mathrm{c}$ & $2889 \mathrm{c}$ & $120 \mathrm{~d}$ & $503 d$ \\
\hline $\mathrm{T}_{2}$ & $68.90 \mathrm{c}$ & $12.79 \mathrm{e}$ & $66.62 \mathrm{bcd}$ & $53.60 \mathrm{bc}$ & $20.15 b$ & $3782 b$ & $211 b c$ & $718 \mathrm{a}$ \\
\hline $\mathrm{T}_{3}$ & $76.09 \mathrm{ab}$ & $14.16 \mathrm{~cd}$ & $72.71 \mathrm{ab}$ & $58.71 \mathrm{a}$ & $21.65 \mathrm{ab}$ & $3996 a b c$ & $227 \mathrm{ab}$ & $818 b c$ \\
\hline $\mathrm{T}_{4}$ & $78.00 \mathrm{a}$ & $17.96 \mathrm{~b}$ & $69.76 \mathrm{abc}$ & $51.74 \mathrm{~cd}$ & $21.80 \mathrm{ab}$ & $4165 \mathrm{a}$ & $259 \mathrm{a}$ & $827 \mathrm{a}$ \\
\hline $\mathrm{T}_{5}$ & $71.71 b c$ & $20.64 \mathrm{a}$ & $63.25 \mathrm{~d}$ & $48.10 \mathrm{~d}$ & $22.21 \mathrm{a}$ & $4181 \mathrm{a}$ & $261 \mathrm{a}$ & $737 a b c$ \\
\hline $\mathrm{T}_{6}$ & $69.47 \mathrm{c}$ & $12.97 \mathrm{de}$ & $68.37 \mathrm{bcd}$ & $50.37 \mathrm{~cd}$ & $20.22 b$ & $3730 b$ & $189 \mathrm{c}$ & $671 \mathrm{c}$ \\
\hline $\mathrm{T}_{7}$ & $74.68 \mathrm{abc}$ & $14.90 \mathrm{c}$ & $73.95 \mathrm{a}$ & $57.17 \mathrm{ab}$ & $21.69 \mathrm{ab}$ & $4057 \mathrm{ab}$ & $260 \mathrm{a}$ & $755 a b c$ \\
\hline L.S.D. at $5 \%$ & 5.36 & 1.25 & 4.98 & 5.74 & 1.60 & 306.5 & 33.0 & 98.9 \\
\hline \multicolumn{9}{|c|}{ Ismailia experiment (sandy soil) } \\
\hline $\mathrm{T}_{1}$ & $38.96 \mathrm{e}$ & $6.38 \mathrm{~d}$ & $36.70 \mathrm{e}$ & $31.88 \mathrm{~d}$ & $11.76 \mathrm{~d}$ & $3060 d$ & $176 \mathrm{~d}$ & $221 d$ \\
\hline $\mathrm{T}_{2}$ & $48.32 \mathrm{~cd}$ & $7.25 b c$ & $46.67 b c$ & $39.11 \mathrm{~b}$ & $15.10 \mathrm{bc}$ & $3655 b$ & $276 a$ & $317 b$ \\
\hline $\mathrm{T}_{3}$ & $54.77 \mathrm{~b}$ & 7.67ab & $51.33 \mathrm{a}$ & $41.31 \mathrm{~b}$ & 16.27ab & $4037 a$ & $257 \mathrm{a}$ & $336 a b$ \\
\hline $\mathrm{T}_{4}$ & $58.56 \mathrm{a}$ & $8.07 \mathrm{a}$ & $49.69 \mathrm{ab}$ & $46.21 \mathrm{a}$ & $18.99 a$ & 4131a & $225 b$ & $335 \mathrm{ab}$ \\
\hline $\mathrm{T}_{5}$ & $44.65 \mathrm{~d}$ & 7.77ab & 43.16 & $40.04 b$ & $18.16 \mathrm{a}$ & $3983 a$ & $275 a$ & $345 a$ \\
\hline $\mathrm{T}_{6}$ & $44.79 \mathrm{~d}$ & $6.83 \mathrm{~cd}$ & $40.69 d$ & $34.96 \mathrm{c}$ & $12.78 \mathrm{~cd}$ & $3362 \mathrm{c}$ & $203 c$ & $286 \mathrm{c}$ \\
\hline $\mathrm{T}_{7}$ & $49.79 \mathrm{c}$ & 7.43abc & $43.51 \mathrm{~cd}$ & $39.53 b$ & $13.79 \mathrm{bcd}$ & $3612 b$ & $274 a$ & $346 a$ \\
\hline L.S.D. at $5 \%$ & 3.74 & 0.68 & 3.84 & 2.52 & 2.63 & 176.7 & 21.2 & 23.7 \\
\hline
\end{tabular}

In Ismailia site

The results showed that the application of Mg-rates from $\left(\mathrm{T}_{2}\right.$ to $\left.\mathrm{T}_{7}\right)$ significantly increased the uptake of $\mathrm{N}, \mathrm{P}, \mathrm{K}, \mathrm{Ca}, \mathrm{Mg}, \mathrm{Fe}, \mathrm{Mn}$ and $\mathrm{Zn}$ by stalk yield of maize grown in sandy soil compared with control $\left(\mathrm{T}_{1}\right)$. The highest stalk yield uptake of $\mathrm{N}, \mathrm{P}, \mathrm{Ca}, \mathrm{Mg}$ and $\mathrm{Fe}$ (58.56, 8.07, $46.21,18.99$ and $4.131 \mathrm{~kg} \mathrm{fed}^{-1}$, respectively) were recorded with the application of $\mathrm{Mg}$ rate $\mathrm{T}_{4}\left(75 \mathrm{~kg} \mathrm{MgSO}_{4} \mathrm{fed}^{-1}\right)$. As well as the highest stalk yield uptake of $\mathrm{K}\left(51.33 \mathrm{~kg} \mathrm{fed}^{-1}\right)$ was recorded with the application of $\mathrm{Mg}$-rate $\mathrm{T}_{3}\left(50 \mathrm{~kg} \mathrm{MgSO}_{4} \quad \mathrm{fed}^{-1}\right)$ then its uptake decreased. So, these results demonstrate the importance of soil supply by $\mathrm{Mg}$ as magnesium sulfate for increasing growth, yield and nutrient uptakes of maize grown in sandy soil and keep balance between nutrient, whereas soil was low in its fertility especially available $\mathrm{Mg}$ (Table 1). In this respect, Szulc (2009) showed that the highest $\mathrm{N}, \mathrm{K}$ and $\mathrm{Mg}$ contents in dry plant matter $\left(37.0,42.18\right.$ and $2.65 \mathrm{~g} \mathrm{~kg}^{-1} \mathrm{DM}$, respectively) were found by maize fertilized with $15 \mathrm{~kg} \mathrm{Mg} \mathrm{ha}^{-1}$ (nearly $62.5 \mathrm{~kg} \mathrm{MgSO}$ $\left.\mathrm{fed}^{-1}\right)$. As well, Ertiftik and Zengin (2016)

Egypt. J. Soil Sci., 57, No. 4 (2017) illustrated that the application of $\mathrm{Mg}$ enhanced the nutritional status of maize through synergic relations between $\mathrm{Mg}$ and $\mathrm{P}, \mathrm{S}, \mathrm{Fe}$ and $\mathrm{Zn}$.

Finally, it can be concluded from the previous results that the response of maize crop grown on clay loam and sandy soils to magnesium fertilization was significant, since the responses were the best in clay loam soil at soil application of $50 \mathrm{~kg}$ magnesium sulfate $\mathrm{fed}^{-1}$ and also at the foliar spray of $0.5 \% \mathrm{Mg}$ twice, and they were the highest in sandy soil with the soil application of $75 \mathrm{~kg}$ magnesium sulfate fed $^{-1}$.

\section{Conclusion}

Under conditions of Dakahlia Governorate (clay loam soils) and Ismalia Governorate (sandy soils), supplying maize with magnesium sulfate as foliar spraying with $0.5 \% \mathrm{Mg}$ twice after 35 and 50 days from sowing for the clayey loam soil and the treatment of $75 \mathrm{Kg}$ magnesium sulfate $\mathrm{fed}^{-1}$ as soil application for the sandy soil can be recommended to get the highest yields and the best quality traits with the addition the recommended doses of other nutrients. 


\section{References}

A.O.A.C. (1990) Official Methods of Analysis of the Association of Official Analytical Chemists. $15^{\text {th }}$ (ed), Published by Association of Official Analytical Chemists Arlington, Virginia, USA.

Ashoub, M. A., Abdel-aziz, I. M. A., Shahin, M. M. and M. N. Gohar (2003) Impact of irrigation and magnesium fertilization on yield, yield components and chemical contents of sunflower. Arab Univ. J. Agric. Sci., Ain Shams Univ., Cairo, 11(1),191-204.

Badran, M. M., Easa, M. O., Abd El-Warth, M. and Raslan,M. I. (2004) Effect of $\mathrm{N}$ and Mg application on wheat plant grown on calcareous soil. Minufiya J. Agric. Res., 29 (6), 1493-1502.

Barlog, P. and Frackowiak-Pawlak, K. (2008) Effect of mineral fertilization on yield of maize cultivars differing in maturity scale. Acta Sci. Pol., Agricultura Poznan, 7(4), 5-17.

Darwish, D. S., Negm, A. Y. and Zahran, F. A. (1997) Effect of magnesium application on production and yield of sunflower. Mansoura Univ. J. Agric. Sci., 22(10), 3375-3381.

Ertiftik, H. and Zengin, M. (2016) Changes in nutrient concentrations of maize (Zea mays var. intendata) leaves under potassium and magnesium application in Central Anatolia. Tarim Bilimleri Dergisi J. Agric. Sci., 22, 606-616.

Fageria, V.D. (2001) Nutrient interactions in crop plants. J. Plant Nutr. 24, 1269-1290.

Gomez, K.A. and Gomez, A.A. (1984) Statistical Procedures for Agricultural Research. $2^{\text {nd }}$ ed., John Wiley and Sons Inc., New York, pp: 95-109.

Gransee A. and Fuhrs, H. (2013) Magnesium mobility in soils as a challenge for soil and plant analysis, magnesium fertilization and root uptake under adverse growth conditions. Plant and Soil, 368, 5-12.

Grzebisz, W. (2004) Potassium in Plant Production. Inter. Potash Institute, Basel, Switzerland, AR Poznan.

Guneş, A., Alparslan, M. and İnal, A. (2002) Plant Nutrition and Fertilization. Ankara Univ., Pub. of Agric. Fac., Ankara (in Turkish), II. Print. Publication No. 1526, Textbook: 479.

Hesse, P.R. (1971) A Text Book of Soil Chemical Analysis. John Murry Publishers, Ltd, 50 Albemarle Street, London.

Izsaki, Z. (2006) Relationship between potassium supplies of the soil and the nutrient concentration of maize (Zea mays L.) leaves. Cereal Res. Commun. 34(1-2), 501-504.
Jackson, M.L. (1967) Soil Chemical Analysis. Printic Hall of India, New Delhi, pp: 144-197.

Jacobsen S.T. (1993) Interaction between Plant Nutrients. Antagonism between potassium, magnesium and calcium. Acta Agric. Scand., Sect. B. Soil and Plant Sci., 43, 1-5.

Jokinen R. (1981) The magnesium status of Finnish mineral soils and the requirement of the magnesium supply. Magnesium-Bulletin, 3(1a),1-5.

Kacar, B. and Katkat, A.V. (2007) Fertilizers and Fertilization Technique. Nobel Pub. No: 1119, Sci. and Biol. Pub. Series: (in Turkish), 34(2): 560.

Kovacevic V., Brkic, I. Banaj; D., Antunovic, M. Simic, D. and Petosic, D. (2004) Magnesium status in corn (Zea mays L.) hybrids and its relations to potassium and calcium. Cereal Res. Commun. 32(1), 41-51.

Marschner, H. (1995) Mineral Nutrition of Higher Plants. Academic, Elsevier.

Mengel, K. and Kirkby,E.A. (2001) Principles of Plant Nutrition. Int. Potash Institute, Bern, Switzerland.

Pathak A. N. and Kalra, Y. P. (1971) Antagonism between potassium, calcium and magnesium in several varieties of hybrid-corn. Zeit. Pflanzen. Boden. 130, 118-124.

Rasul, G.A., Esmail, A.O. and Mekha, R. J. (2011) The role of magnesium in increasing of phosphorus fertilizer efficiency and wheat yield. Mesopotamia J. Agric. 39 (2), 33-39.

Römheld, V. and Kirkby, E. A. (2007) Magnesium functions in crop nutrition and yield. Proc. Conf. in Cambridge (7 $7^{\text {th }}$ Dec. 2007), 151-171.

Schulte E. E. (2004) Soil and Applied Magnesium. Wisconsin County Extension-Univ. of WisconsinExtension, RP.-08-2004.

Singh B. and Singh, B. L. (1986) Interactions of potassium, magnesium and farmyard manure on maize production. Proc. Indian Natn. Sci. Acad. B52 No. 2 pp 291-295.

Szulc, P. (2009) Effect of nitrogen fertilization and methods of magnesium application on chlorophyll content, accumulation of mineral components, and morphology of two maize hybrid types in the initial growth period. Part 1: content of chlorophyll and mineral components. Acta Scientiarum PolonorumAgricultura Poznan, 8(2), 43-50. part 2: uptake of mineral components. Acta Scientiarum PolonorumAgricultura Poznan, 8 (2),51-62.

(Received / / ; acecpted // )

Egypt. J. Soil Sci., 57, No. 4 (2017) 


\section{تأثير التسميد بالماغنسيوم على المحصول وامتصاص العناصر الغذائية للذرة الثامية المنزرعه في تربتين مختلفتين}

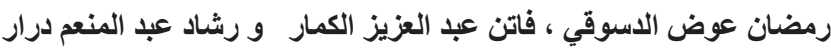

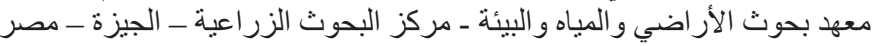

الماغنسيوم أحد العناصر الغذائية الضرورية لنمو النبات و التي تظهر أعر اض نقصده نتيجة لانخفاض محتوي

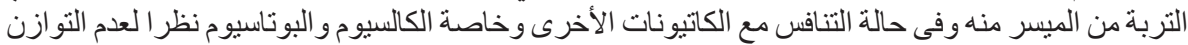

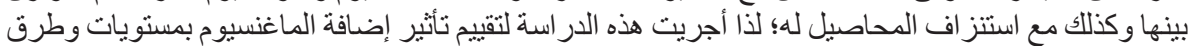

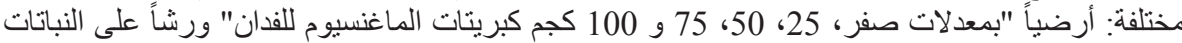

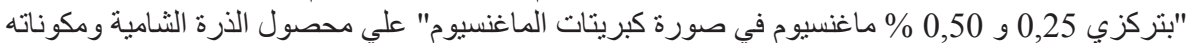

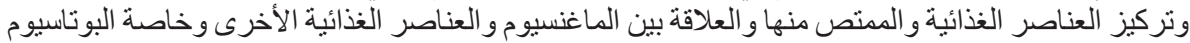

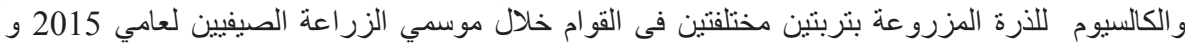
2016" N, 31 20

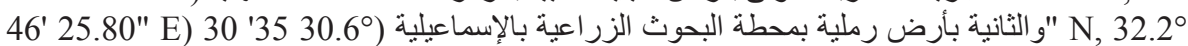
14' 50" E) - مصر

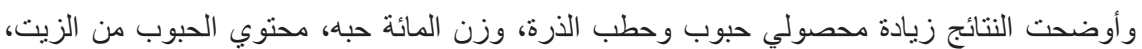

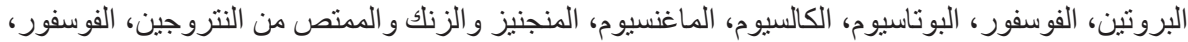

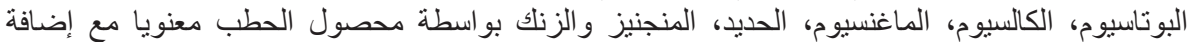

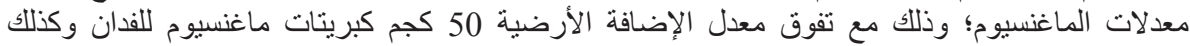

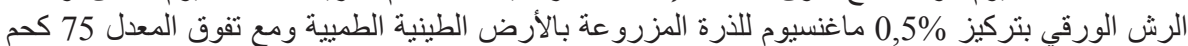

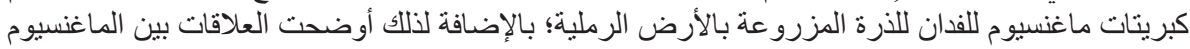

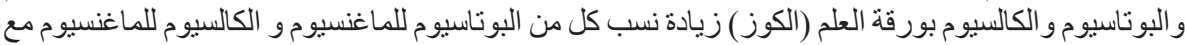
الرش الورقي للماغنسيوم و الإضافة الأرضية لكبريتات الماغنسيوم حتي معدل 50 كجم للفدان في كلا التربتين. 